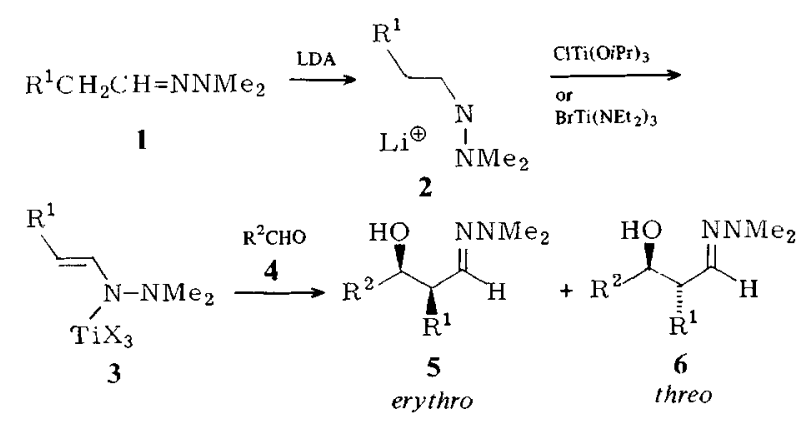

Table 1. Erythro-selective addition of titanium reagents 3 to aldehydes 4 .

\begin{tabular}{|c|c|c|c|c|}
\hline$R^{1}$ & $\mathrm{X}$ & $\mathbf{R}^{2}$ & $\begin{array}{l}\text { Conversion } \\
{[\%]}\end{array}$ & $5: 6$ \\
\hline $\mathrm{CH}_{3}$ & $\mathrm{O} i \mathrm{Pr}$ & $\mathrm{C}_{6} \mathrm{H}_{5}$ & a $(80)$ & $91: 9$ \\
\hline $\mathrm{CH}_{3}$ & $\mathrm{NEt}_{2}$ & $\mathrm{C}_{6} \mathrm{H}_{5}$ & a (61) & $85: 15$ \\
\hline $\mathrm{C}_{6} \mathrm{H}_{5}$ & $\mathrm{O} i \mathrm{Pr}$ & $\mathrm{C}_{6} \mathrm{H}_{5}$ & b (95) & $98: 2$ \\
\hline $\mathrm{C}_{6} \mathrm{H}_{5}$ & OiPr & $p-\mathrm{NO}_{2} \mathrm{C}_{6} \mathrm{H}_{4}$ & c (40) & $98: 2$ \\
\hline $\mathrm{C}_{6} \mathrm{H}_{5}$ & $\mathrm{OiPr}$ & $\mathrm{CH}_{3}$ & d (95) & $96: 4$ \\
\hline $\mathrm{C}_{6} \mathrm{H}_{5}$ & $\mathrm{NEt}_{2}$ & $\mathrm{CH}_{3}$ & d $(50)$ & $\approx 90: 10$ \\
\hline $\mathrm{C}_{6} \mathrm{H}_{5}$ & $\mathrm{O} i \mathrm{Pr}$ & $\mathrm{CH}\left(\mathrm{CH}_{3}\right)_{2}$ & e (78) & $98: 2$ \\
\hline$\left(\mathrm{CH}_{3}\right)_{2} \mathrm{CH}$ & $\mathrm{OiPr}$ & $\mathrm{C}_{6} \mathrm{H}_{5}$ & f $(78)$ & $94: 6$ \\
\hline $\mathrm{CH}_{3}$ & $\mathrm{O} i \mathrm{Pr}$ & $\mathrm{CH}_{3}$ & g (61) & $95: 5$ \\
\hline $\mathrm{CH}_{3}$ & $\mathrm{OiPr}$ & $\mathrm{C}\left(\mathrm{CH}_{3}\right)_{3}$ & h $(70)$ & $93: 7$ \\
\hline
\end{tabular}

pressure liquid chromatography ${ }^{[1]}$. The product ratio was determined by analysis of the $400-\mathrm{MHz}{ }^{1} \mathrm{H}-\mathrm{NMR}$ spectra.

The erythro-selectivity is also observed with titanated ketone-hydrazones $(e . g .7 \rightarrow \mathbf{8})$, a finding which is to be compared with the erythro-selective behavior of titanium enolates from ketones ${ }^{[5]}$.

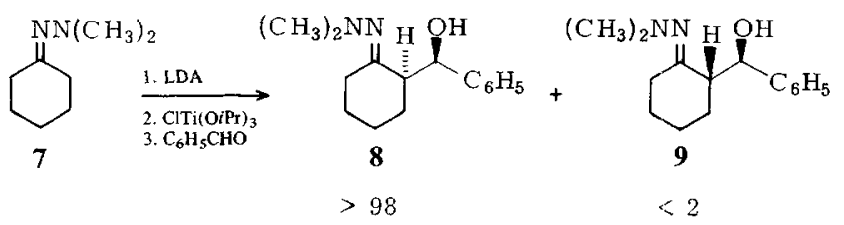

In the case of $3\left(\mathrm{R}^{1}=\mathrm{C}_{6} \mathrm{H}_{5}, \mathrm{X}=\mathrm{N}\left(\mathrm{C}_{2} \mathrm{H}_{5}\right)_{2}\right)$ it was possible to record a ${ }^{1} \mathrm{H}-\mathrm{NMR}$ spectrum which is in line with the $E$-configuration. The observed stereoselectivity is therefore surprising, because $E$-configurated ketone-enolates usually react threo-selectively ${ }^{[1,2]}$. In the case of a cyclic transition state, both chair and boat conformations are conceivable.

Aside from chlorotitanium triisopropoxide, titanium tetraisopropoxide can also be used for the titanation. However, in this case ate-complexes are formed which show less pronounced erythro-selectivity. Finally, titanated Schiff bases likewise behave erythro-selectively.

$$
\begin{array}{r}
\text { Received: July } 13,1982 \text { [Z } 90 \text { IE] } \\
\text { revised: August } 19,1982
\end{array}
$$
German version: Angew. Chem. 94 (1982) 872 The complete manuscript of this communication appears in: Angew. Chem. Suppl. 1982, 1899-1905

CAS Registry numbers:

$1 \quad\left(\mathrm{R}^{\prime}=\mathrm{CH}_{3}\right), 7422-93-7 ; 1 \quad\left(\mathrm{R}^{\prime}=\mathrm{C}_{6} \mathrm{H}_{5}\right), 65259-56-5 ; 1 \quad\left(\mathrm{R}^{\prime}=\left(\mathrm{CH}_{3}\right)_{2} \mathrm{CH}\right)$, $13063-58-6 ; 3 \quad\left(\mathrm{R}^{\prime}=\mathrm{CH}_{3}, \quad \mathrm{X}=\mathrm{OCH}\left(\mathrm{CH}_{3}\right)_{2}\right), 83314-04-9 ; \quad 3 \quad\left(\mathrm{R}^{\prime}=\mathrm{CH}_{3}\right.$, $\left.\mathrm{X}=\mathrm{N}\left(\mathrm{C}_{2} \mathrm{H}_{5}\right)_{2}\right), 83314-05-0 ; 3 \quad\left(\mathrm{R}^{\prime}=\mathrm{C}_{6} \mathrm{H}_{5}, \mathrm{X}=\mathrm{OCH}\left(\mathrm{CH}_{3}\right)_{2}\right), 83314-06-1 ; 3$ $\left\langle R^{\prime}=\mathrm{C}_{6} \mathrm{H}_{5}, \mathrm{X}=\mathrm{N}\left(\mathrm{C}_{2} \mathrm{H}_{5}\right)_{2}\right), 83314-07-2 ; 3\left(\mathrm{R}^{\prime}=\left(\mathrm{CH}_{3}\right)_{2} \mathrm{CH}, \mathrm{X}=\mathrm{OCH}\left(\mathrm{CH}_{3}\right)_{2}\right)$, 83314-08-3; $4\left(\mathrm{R}^{2}=\mathrm{C}_{6} \mathrm{H}_{5}\right), \quad 100-52-7 ; 4 \quad\left(\mathrm{R}^{2}=p-\mathrm{NO}_{2} \mathrm{C}_{6} \mathrm{H}_{4}\right), \quad 555-16-8 ; 4$

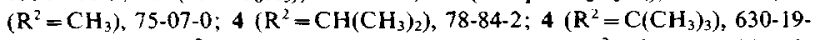
3; $5\left(R^{\prime}=\mathrm{CH}_{3}, \mathrm{R}^{2}=\mathrm{C}_{6} \mathrm{H}_{5}\right)$, 83314-09-4; $5\left(\mathrm{R}^{\prime}=\mathrm{C}_{6} \mathrm{H}_{5}, \mathrm{R}^{2}=\mathrm{C}_{6} \mathrm{H}_{5}\right), 83314-10-$ 7; $5\left(\mathrm{R}^{\prime}=\mathrm{C}_{6} \mathrm{H}_{5}, \mathrm{R}^{2}=p-\mathrm{NO}_{2}\left(\mathrm{C}_{6} \mathrm{H}_{4}\right), 83314-11-8 ; 5\left(\mathrm{R}^{\prime}=\mathrm{C}_{6} \mathrm{H}_{5}, \mathrm{R}^{2}=\mathrm{CH}_{3}\right)\right.$, 83314-12-9; $5\left(\mathrm{R}^{\prime}=\mathrm{C}_{6} \mathrm{H}_{5}, \mathrm{R}^{2}=\mathrm{CH}\left(\mathrm{CH}_{3}\right)_{2}, 83314-13-0 ; 5\left(\mathrm{R}^{\prime}=\left(\mathrm{CH}_{3}\right)_{2} \mathrm{CH}\right.\right.$, $\left.\mathbf{R}^{2}=\mathrm{C}_{6} \mathrm{H}_{5}\right), 83314-14-1 ; \quad 5 \quad\left(\mathbf{R}^{\prime}, \quad \mathbf{R}^{2}=\mathrm{CH}_{3}\right), 83314-15-2 ; \quad 5 \quad\left(\mathbf{R}^{\prime}=\mathrm{CH}_{3}\right.$, $\left.\mathrm{R}^{2}=\mathrm{C}_{(}\left(\mathrm{CH}_{3}\right)_{3}\right), \quad 83314-16-3 ; \quad 6 \quad\left(\mathrm{R}^{\prime}=\mathrm{CH}_{3}, \quad \mathrm{R}^{2}=\mathrm{C}_{6} \mathrm{H}_{5}\right), \quad 83314-17-4 ; \quad 6$ $\left(R^{\prime}=\mathrm{C}_{6} \mathrm{H}_{5}, \mathrm{R}^{2}=\mathrm{CH}_{3}\right), 83314-18-5 ; 7,10424-93-8 ; 8,83314-19-6 ; 12,83314-$ 20-9; $N$-propylidenecyclohexanamine, 1195-49-9; titanium tetraisopropoxide, 546-68-9; CI[TiOCH $\left.\left(\mathrm{CH}_{3}\right)_{2}\right]_{3}, 20717-86-6 ; \mathrm{TiCl}_{4}, 7550-45-0 ; \mathrm{BrTi}\left(\mathrm{NEt}_{2}\right)_{3}$, 24690-84-4.
[1] C. H. Heathcock in T. Durst, E. Buncel: Comprehensive Carbanion Chemistry, Vol. 2, Elsevier, Amsterdam 1981.

[2] D. A. Evans, J. V. Nelson, T. R. Taber, Top. Siereochem. 13 (1982) 1.

[3] M. T. Reetz, R. Peter, unpublished results.

[4] K. G. Davenport, H. Eichenauer, D. Enders, M. Newcomb, D. E. Bergbreiter, J. Am. Chem. Soc. 101 (1979) 5654.

[5] M. T. Reetz, R. Peter, Tetrahedron Lett. 22 (1981) 4691.

\section{Theoretical Investigations on the Valence Tautomerism between 1,6-Methanol[10]annulene and Tricyclo[4,4.1.0 ${ }^{1,6}$ |undeca-2,4,7,9-tetraene}

\section{By Dieter Cremer* and Bernhard Dick}

1,6-Methano[10]annulene 1 must, on the basis of its physical and chemical properties, be described as a Hückel aromatic system with a delocalized $\pi$-electron decet ${ }^{[1 \mathrm{a}-d]}$. Investigations on C-11-substituted 1,6-methano[10]annulenes, however, suggest that 1 can transform into the valence tautomer tricyclo[4.4.1.0 $\left.0^{1,6}\right]$ undeca-2,4,7,9-tetraene 2 in solution ${ }^{[1 c, d]}$. There is the possibility of a rapid reversible valence tautomerism of the type $1 \rightleftharpoons 2$, similarly to that assumed for the system cycloheptatriene 3 - norcaradiene $4^{[l e-g]}$.

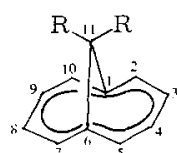

1, $\mathrm{R}=\mathrm{H}$

5, $\mathrm{R}=\mathrm{CN}$<smiles>C1=CC=CCC=C1</smiles>
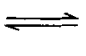

2, $\mathrm{R}=\mathrm{H}$

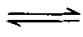

6, $R=C N$
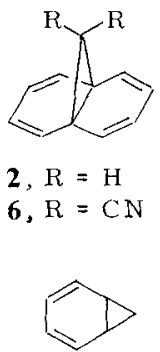

According to experimental and theoretical estimates ${ }^{[2]}, 4$ is destabilized by about $4-12 \mathrm{kcal} / \mathrm{mol}$ compared to 3 . Accordingly, the equilibrium $\mathbf{3} \rightleftharpoons \mathbf{4}$ is shifted far over to the side of the cycloheptatriene. However, detection of the norcaradiene component has so far only been possible in an indirect way. Thus, 3 reacts like 1 with dienophiles to give Diels-Alder products, indicating a previous rearrangement $3 \rightleftharpoons 4$ or $1 \rightleftharpoons 2$. However, it cannot be ruled out that the norcaradiene component is first formed at the moment of reactive collision with the dienophile ${ }^{[2 a}$.

To clarify this problem we have determined the energy profile of the valence tautomeric processes $1 \geqslant 2$ and $3 \rightleftharpoons 4$, respectively, by $a b$ initio calculations and therefrom obtained the energy differences $\Delta E=E(2)-E(1)$ and $\Delta E=E(4)-E(3)^{[3]}$. After taking into account vibration and entropy effects values of 4.5 and $5.6 \mathrm{kcal} / \mathrm{mol}$, respectively, result for the difference in the free energies $\Delta G^{0}$, which corresponds to concentrations of about $0.05 \% 2$ and $0.01 \% 4$ at room temperature.

The valence tautomerization of 1 , like that of 3 , is characterized by an asymmetric double-well potential (Fig. 1). According to our calculations, an asymmetric single-well potential, as has been discussed for the 11-cyano-11-methyl derivative ${ }^{[4 a]}$, can be ruled out for the rearrangement $1 \rightarrow 2$. For the energy barriers $\Delta E^{*}$ of the forward and reverse reactions, we find values of 7.3 and $2.3 \mathrm{kcal} / \mathrm{mol}$, respectively. These values are about $3 \mathrm{kcal} / \mathrm{mol}$ smaller than the barriers calculated for the equilibrium $3 \rightleftharpoons 4$. Appar-

[*] Priv.-Doz. Dr. D. Cremer, Dr. B. Dick

Lehrstuhl für Theoretische Chemie der Universität

Greinstrasse 4, D-5000 Köln 41 (Germany) 
ently formation of the cyclopropane bond is favored as a result of the shorter 1,6-distance in $1(2.26 \AA$ as opposed to $2.50 \AA$ in $3^{[3]}$ ), whereas in 2 the interaction of the Walsh orbitals of the three-membered ring with the $\pi$-orbitals of the butadiene moieties indicates the far better $\pi$-conjugation in 1.
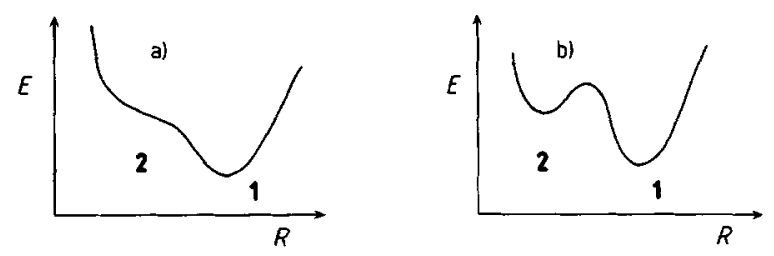

Fig. 1. Schematic representation a) of an asymmetric single-well potential and b) of an asymmetric double-well potential for the valence tautomeric equilibrium $1 \rightleftharpoons 2 . R$ is distance between $C-1$ and C-6.

According to experimental and theoretical investigations on cycloheptatrienes, substituents can shift the valence tautomeric equilibrium to the side of the norcaradiene ${ }^{[4 b-e]}$. Thus, Ciganek synthesized 7,7-norcaradienedicarbonitrile as the first norcaradiene derivative in this way ${ }^{[4]}$.

The electronic influence of the two $\mathrm{CN}$ groups has been calculated to amount to about $10 \mathrm{kcal} / \mathrm{mol}^{[3]}$ in the case of the cycloheptatriene. If this value is extended to the system $1 \rightleftharpoons 2$, then it can be predicted that tricyclo[4.4.1.0 $\left.0^{1,6}\right]$ undeca-2,4,7,9-tetraene-11,11-dicarbonitrile 6 is more than 5 $\mathrm{kcal} / \mathrm{mol}$ more stable than the valence tautomeric $1,6-\mathrm{me}-$ thano[10]annulene-11,11-dicarbonitrile 5. This prediction is confirmed by the synthesis of 6 and its spectroscopic and structural chemical characterization carried out by Vogel et al. ${ }^{[5]}$

Received: July 13, 1982 [Z 92 IE] Revised: September 20, 1982 German version: Angew. Chem. 94 (1982) 877

CAS Registry numbers:

$1,2443-46-1 ; 2,174-23-2 ; 3,544-25-2 ; 4,14515-09-4 ; 5,61997-35-1 ; 6$, 61997-37-3.

[1] a) E. Vogel, H. D. Roth, Angew. Chem. 76 (1964) 145; Angew. Chem. Int. Ed. Engl. 3 (1964) 228; b) E. Vogel, Pure Appl. Chem. 20 (1969) 237; c) H. Günther, H. Schmickler, W. Bremser, F. A. Straube, E. Vogel, Angew. Chem. 85 (1973) 585; Angew. Chem. Int. Ed. Engl. 12 (1973) 570; d) H. Günther, H. Schmickler, Pure Appl. Chem. 44 (1975) 807; e) G. Maier, Angew. Chem. 79 (1967) 446; Angew. Chem. Int. Ed. Engl. 6 (1967) 402; f) E. Vogel, W. Wiedemann, H. D. Roth, J. Eimer, H. Günther, Liebigs Ann. Chem. 759 (1972) 1; g) M. B. Rubin, J. Am. Chem. Soc. 103 (1981) 7791.

[2] a) T. Tsuji, S. Teratake, H. Tanida, Bull. Chem. Soc. Jpn. 42 (1969) 2033; b) P. M. Warner, S. L. Lu, J. Am. Chem. Soc. 102 (1980) 331; c) M. J. S. Dewar, Pure Appl. Chem. 44 (1975) 767; d) D. M. Hayes, S. D. Nelson, W. A. Garland, P. A. Kollman, J. Am. Chem. Soc. 102 (1980) 1255.

[3] The equilibrium geometries of 1 to 4 were determined by means of the MNDO method and by Hartree-Fock (HF) calculations with minimal basis (STO-3G). The potential curve for the transformation $1 \rightleftharpoons 2$ was determined by HF/4-31G calculations. The absolute energies for 1 and 2 are -421.67075 and -421.66278 Hartree, respectively. In the case of 3 and 4 additional $\mathrm{HF} / 6-31 \mathrm{G}^{*}$ calculations were carried out $[E(3)=-269.68035, E(4)=-269.67128$ Hartree]. Correlation effects were estimated according to the Møller-Plesset perturbation method (2nd order). Finally, the zero point vibration energies as well as vibration contributions to enthalpy and entropy have been determined by force field calculations (D. Cremer, B. Dick, D. Christen, unpublished results).

[4] a) R. Bianchi, T. Pilati, M. Simonetta, J. Am. Chem. Soc. 103 (1981) 6426; b) E. Ciganek, ibid. $87(1965) 652,1149$; c) M. Görlitz, H. Günther, Tetrahedron 25 (1969) 4467; d) R. Hoffmann. Tetrahedron Lett. 1970, 2907; e) H. Günther, ibid. 1970, 5173.

[5] E. Vogel, T. Scholl, J. Lex, G. Hohlneicher, Angew. Chem. 94 (1982) 878; Angew. Chem. Int. Ed. Engl. 21 (1982) 869
Synthesis of $\operatorname{Pd}\left(\eta^{2}-\mathrm{CH}_{2}=\mathrm{C}_{5} \mathrm{Me}_{4}\right) \mathrm{L}_{2}$ : Formation of a Fulvene Ligand by Metal-Assisted $\mathrm{H}$-Shift from Pentamethylcyclopentadienyl**

\section{By Hans-Jürgen Kraus and Helmut Werner*}

Dedicated to Professor Rudolf Hoppe on the occasion of his 60 th birthday

In connection with our studies on the chemistry of dinuclear palladium complexes of the type $\left(\mathrm{C}_{5} \mathrm{H}_{5}\right)(2$ $\left.\mathrm{RC}_{3} \mathrm{H}_{4}\right) \mathrm{Pd}_{2} \mathrm{~L}_{2}(1)^{[10]}$ we attempted the preparation of the corresponding pentamethylcyclopentadienyl compounds via reaction sequence $(a)$. We expected these compounds to exhibit greater kinetic stability than the $\mathrm{C}_{5} \mathrm{H}_{5}$ complexes 1 regarding cleavage of the $\mathrm{C}_{5} \mathrm{Me}_{5}-\mathrm{Pd}_{2}$ bond ${ }^{[12]}$.

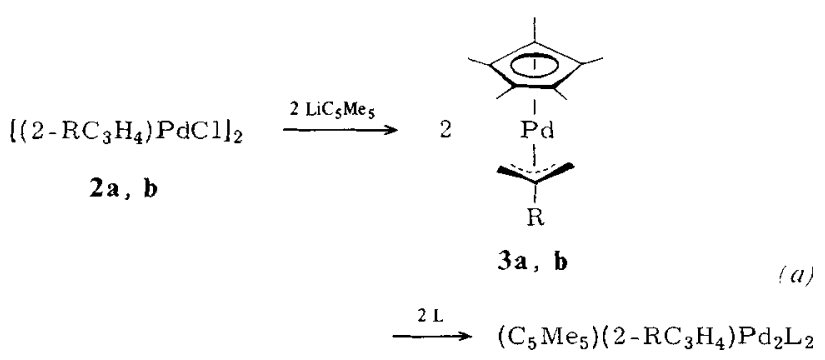

(a, $\mathrm{R}=\mathrm{Me} ; \mathrm{b}, \mathrm{R} \boldsymbol{\mathrm { a }} \mathrm{CMe_{3 }}$ )

The reaction of $\mathbf{2 a}$ or $\mathbf{2 b}$ with $\mathrm{LiC}_{5} \mathbf{M e}_{5}$ in pentane $\left(25^{\circ} \mathrm{C}, 2 \mathrm{~h}\right.$ ) leads to $\mathbf{3 a}$ and $\mathbf{3 b}$, respectively ( $\mathrm{ca} .85 \%$ yield, red crystals, m.p. $15-17^{\circ} \mathrm{C}$ and $58^{\circ} \mathrm{C}$, respectively, correct elemental analysis, ${ }^{1} \mathrm{H}-\mathrm{NMR}$ and mass spectra).

3b does not react with $\mathrm{P}(i \mathrm{Pr})_{3}$ or $\mathrm{PPh}_{3}$, even on prolonged heating at $50-60^{\circ} \mathrm{C}$. Reaction with $\mathrm{PMe}_{2} \mathrm{Ph}$ and $\mathrm{PMePh}_{2}$ leads to cleavage of both the $\mathrm{C}_{5} \mathrm{Me}_{5}-\mathrm{Pd}$ as well as the allyl-Pd bond, with formation of the known palladium(0) compounds $\operatorname{Pd}\left(\mathrm{PR}_{3}\right)_{4}$. In contrast, the reactions with $\mathrm{PMe}_{3}$ and $\mathrm{P}(\mathrm{OMe})_{3}$ in toluene $\left(50-60^{\circ} \mathrm{C}, 5 \mathrm{~h}\right)$ afford the 1,2,3,4-tetramethylfulvene complexes 4 and 5 in $80-$ $90 \%$ yield as bright yellow, air-sensitive solids which are readily soluble in all the common solvents and can be stored almost indefinitely at $-30^{\circ} \mathrm{C}$ under nitrogen.

The room-temperature ${ }^{1} \mathrm{H}$-NMR spectra of 4 and 5 (in $\mathrm{C}_{6} \mathrm{D}_{6}$ ) indicate that the compounds have a fluxional structure in solution. Considerably broadened singlets are observed both for the protons of the exocyclic $\mathrm{CH}_{2}$-groups as well as for the methyl protons of the ring. Signal sharpening occurs (in $\left(\mathrm{CD}_{3}\right)_{2} \mathrm{CO}$ ), and on cooling at $-10^{\circ} \mathrm{C}$ (4) and $-25^{\circ} \mathrm{C}(5)$, respectively, the splitting pattern to be expected for the constitution given in Scheme 1 is observed. From the large upfield shift of the signal of the $\mathrm{C}=\mathrm{CH}_{2}$ protons of $\delta=5.47$ in the free tetramethylfulvene to $\delta=2.54$ and 3.04 in 4 and 5 , respectively, the large $\mathrm{PH}$ coupling constants, and the observation of two (and not of four) signals for the $\mathrm{C}-\mathrm{CH}_{3}$ groups, it can be concluded that the $\mathrm{PdL}_{2}$ moiety is coordinated to the exocyclic $\mathrm{C}=\mathrm{C}$ double bond. The palladium atom should lie in a plane with the two phosphorus atoms and the carbon atoms of the $\mathrm{C}=\mathrm{CH}_{2}$ bond. The platinum compounds $\mathrm{Pt}\left(\eta^{2}-\right.$ $\left.\mathrm{CH}_{2}=\mathrm{C}_{5} \mathrm{Ph}_{4}\right) \mathrm{L}_{2} \quad\left(\mathrm{~L}=\mathrm{PPh}_{3}, \quad \mathrm{PMePh}_{2}, \mathrm{PMe}_{2} \mathrm{Ph}, \quad \mathrm{AsPh}_{3}\right.$,

[*] Prof. Dr. H. Werner, Dr. H.-J. Kraus Institut für Anorganische Chemie der Universität Am Hubland, D-8700 Würzburg (Germany)

[**] Investigations on the Reactivity of Metal- $\pi$-Complexes, Part 38. This work constitutes part of the Dissertation by H.-J. Kraus, Universität Würzburg 1981.- Part 37: [12] 